\section{Volume based closed-cycle Hardgrove grindability method}

The Mining-Geology-Petroleum Engineering Bulletin UDC: 66.03

DOI: 10.17794/rgn.2019.4.2

Original scientific paper

\author{
Gábor Mucsi'; Ádám Rácz²; Gergely Mag³, Gábor Antal4; Barnabás Csőke5 \\ 1,2,3,4,5Institute of Raw Material Preparation and Environmental Processing, University of Miskolc, 3515 Miskolc, Hungary
}

\begin{abstract}
This paper deals with the development of a volume based closed-cycle grindability test method based on the recently introduced Universal Hardgrove mill and procedure. Five model materials with various origin and material characteristics (hardness, grindability, heterogeneity) were chosen for the experiments, i.e. limestone, quartz, andesite, basalt and cement clinker. The grindability of the material was characterized simultaneously in four various ways: 1) the standard Hardgrove Grindability test (HGI), 2) Bond work index calculated from HGI, 3) the conventional Bond test and 4) the closed-cycle volume based grindability test in the Universal Hardgrove mill. The grindability coefficient $(\mathrm{G})$, and the cumulative particle size distribution of $80 \%$ passing size $\left(\mathrm{x}_{80}\right)$ of the product of the closed-cycle Hardgrove test were determined. Relative deviation of the above parameters was very good (in most cases lower than $3 \%$ ) which indicates the new proposed method as a robust procedure for rapid determination of specific grinding energy of closed cycle grinding in ring mills. Therefore, this test is able to ease the optimization of grinding conditions relatively fast and reliably.
\end{abstract}

\title{
Keywords
}

Universal Hardgrove mill, Bond index, grindability, specific grinding work, closed-cycle grinding.

\section{Introduction}

Grinding has a very wide range of application in the industry, i.e. minerals, wastes, biomass, chemicals, pharmaceuticals, etc. (Juhász and Opoczky, 1990; Nagy, 2010; Mucsi and Rácz, 2017; Mucsi et al, 2019). The grindability or the resistance of materials against a mechanical effect is a very important material characteristic. Namely, this property significantly affects the milling operation, the efficiency of the grinding process, the power requirement of the grinding, etc. Mill dimensioning, optimization and the specific energy demand determination are based on the knowledge of the grindability of a given material.

Grindability is generally characterized by the grinding work required for a unit weight or a unit volume of material. This material property is determined in a standardized apparatus under exactly defined conditions. The most widely known and utilized grindability tests are the Bond, Hardgrove and Zeisel methods (ASTM D409-71, 1931; Bond, 1943; Zeisel, 1953).

In the following segment, some relevant developments are presented briefly concerning grindability tests which were achieved in the last decades, moreover recalculation equations of various grindability numbers are described.

Corresponding author: Gábor Mucsi

ejtmucsi@uni-miskolc.hu
Relationships between Bond and Hardgrove grindability numbers were investigated by various researchers, alongside McIntyre and Plitt (1980), who revealed a correlation based on the experimental results of $11 \mathrm{~min}-$ eral samples (ores, gypsum, limestone, coals). They describe the grindability test introduced by Bond and Maxson in 1943 (Bond and Maxson, 1943), as a complicated and time-consuming method, where the time requirement could be as long as 20 hours, thus limiting its applicability. Although, they agree on the importance of the Bond-test utilized in the selection and dimension of mills or crushers.

The relationship between the Bond work index $\left(\mathrm{W}_{\mathrm{iB}}\right)$ and the Hardgrove Grindability Index (HGI) suggested by Bond (1954) and corrected later (Bond, 1961; Bond, 1964) can be described with Equation 1 and 2 respectively.

$$
\begin{gathered}
W_{i B}=\frac{88}{H G I^{0,5}} \\
W_{i B}=\frac{435}{H G I^{0,91}}
\end{gathered}
$$

Where:

$\mathrm{W}_{\mathrm{iB}}-$ Bond work index $(\mathrm{kWh} / \mathrm{t})$,

HGI - Hardgrove Grindability Index (-).

Regarding lignite grindability, Csőke et al. (2003 a) realized that Eq. 2 can be used for other minerals as well with homogeneous textures, but it is not suitable for het- 
Table 1. Chemical composition (main components) of the samples

\begin{tabular}{|l|c|c|c|c|c|c|c|c|c|c|}
\hline & $\mathbf{S i O}_{2}$ & $\mathbf{A l}_{2} \mathbf{O}_{\mathbf{3}}$ & $\mathbf{M g O}$ & $\mathbf{C a O}$ & $\mathbf{N a}_{2} \mathbf{O}$ & $\mathbf{K}_{2} \mathbf{O}$ & $\mathbf{F e}_{2} \mathbf{O}_{3}$ & $\mathbf{M n O}$ & $\mathbf{T i O}_{2}$ & $\mathbf{P}_{2} \mathbf{O}_{\mathbf{5}}$ \\
\hline & $\%$ & $\%$ & $\%$ & $\%$ & $\%$ & $\%$ & $\%$ & $\%$ & $\%$ & $\%$ \\
\hline Sand & 87.7 & 5.4 & 0.32 & 0.31 & 1.04 & 1.09 & 1.00 & 0.012 & 0.156 & 0.042 \\
\hline Limestone & 0.8 & 0.3 & 0.21 & 54.2 & 0.02 & 0.09 & 0.07 & $<0.005$ & 0.006 & 0.071 \\
\hline Andesite & 45.8 & 13.9 & 4.07 & 8.26 & 2.89 & 2.56 & 7.49 & 0.132 & 1.779 & 0.797 \\
\hline Basalt & 46.0 & 12.9 & 5.33 & 7.81 & 2.74 & 2.27 & 8.10 & 0.148 & 1.731 & 0.753 \\
\hline Clinker & 22.3 & 4.4 & 1.28 & 44.2 & 0.22 & 1.22 & 1.51 & 0.197 & 0.139 & 0.164 \\
\hline
\end{tabular}

erogeneous and fibrous lignite which resulted in a big difference between Bond work indices.

However, the relevance of secondary materials in the cement industry are increasing more and more nowadays, and they are characterized as very heterogeneous materials. The grindability of secondaries is reported by Dvorak et al. (2016) by comparing the co-milling and separate grinding. Concerning a heterogenous materials' grindability, Gável et al. (2000) revealed the relationship between the material structure and technological parameters, grindability of clinker grinding. Agus and Waters (1971) introduced the so-called volume based Hardgrove grindability test using $36 \mathrm{~cm}^{3}$ material which resulted in accurate grindability values even in the case of different density materials. However, based on the literature, this method was not used in practice.

Haese et al (1975) carried out Hardgrove, Zeisel and Bond grindability tests with limestone, marble and loess samples. Comparing their results in the unit of $\mathrm{kWh} / \mathrm{t}$, they identified that neither of the above methods were in accordance with each other. The difference between the Hardgrove- and Zeisel-numbers were found to be too high. However, if we do not take into consideration the low grindability loess samples, the difference is in the range from $-23.8 \%$ to $+6.3 \%$. Contrary to this, by comparing the Hardgrove and Bond results, a relatively lower difference was achieved, namely from $-13.1 \%$ to $+5.6 \%$. Finally, a weak correlation was found in the comparison of the Zeisel and the Bond experimental data which resulted in a $-18.2 \%$ to $+14.0 \%$ difference.

Shi and Zuo (2014) improved a method for coal breakage characterization. This paper presents the breakage testing method and results, while Shi (2014 a) gives a breakage model that determines the energy-size reduction relationship for multi-components of particle size and coal density. Furthermore, Shi (2014b) demonstrates the applications of the model for HGI predictions and coal breakage simulations. The new method incorporates hardware for a fine particle breakage characterization test, the JKFBC (JK Fine-particle Breakage Characteriser), a device modified from the standard HGI mill, which has a precision torque meter installed to record energy utilization during the experiments. Using an Australian and a Chinese coal sample collected from power stations, this paper demonstrates the effects of particle size and density on coal breakage, and elucidates the deficiencies associated with the traditional HGI test.

Development in grinding theories (Juhász and Opoczky, 1990) and grindability tests are focusing mainly on conventional ball mills (Smith and Lee, 1968; Beke, 1974; Deister, 1987; Levin, 1989; Magdalinovic, 1989; Deniz et al., 2003; Morrell, 2004, Todorovic et al., 2017) only a few papers deal with other methods for ring mills (Shi and Zuo, 2014, Shi, 2014 a).

Senetakisn et al. (2013) carried out a series of micromechanical tests in order to investigate the inter-particle coefficient of friction in quartz minerals. For this purpose, a custom-built inter-particle loading apparatus was designed and constructed. This apparatus can perform shearing tests in contact with soil minerals of particleparticle type in the range of very small displacements. The laboratory data showed that the effects of the normal force and the sliding velocity on the coefficient of dynamic friction are not significant, while dry and saturated surfaces had similar frictional characteristics.

Ring mills i.e. bowl mills are more and more applied apparatuses in a very wide range of the mineral processing industry from cement grinding to ore preparation due to their favourable energy consumption compared with the tumbling ball mill (Nagy, 2010). Based on these preliminaries, it can be identified that most of the grindability tests or simulation methods developed recently are focusing mainly on ball mills in the spite of the fact that ring mills are more and more widely used in industrial practice. Therefore, it is important to develop a grindability test method simulating ring mill conditions, additionally, operating in a closed-cycle similarly to the Bond-test. To date, no such literature is available on the closed-cycle volume based Hardgrove grindability test.

Starting from the above lack in available grindability test, the main aim of our research was to develop such a grindability testing principle and method which can be applied for the determination of grindability in various industrial fields (mineral processing, cement industry, waste treatment,...) in order to determine the specific grinding energy, which can be successfully used in designing new grinding facilities, and in the optimization of the existing operations, resulting in significant savings in both investment and operating costs. 


\section{Materials and methods}

\subsection{Materials}

Five model materials with various grindability characteristics, hardness and origin were chosen for the experimental investigation: andesite, basalt, clinker, limestone and quartz. For the experimental investigation, two sedimentary rocks (sand and limestone), two volcanic (andesite and basalt) and one artificial rock (clinker) were used. The chemical composition of the raw materials is found in Table 1.

The chemical composition of the raw materials was measured using a Rigaku Supermini 200 type X-ray fluorescence apparatus. After determination of the loss on ignition (L.O.I.), $1.000 \mathrm{~g}$ of the burned powder sample was mixed with $6.000 \mathrm{~g}$ of lithium tetraborate $\left(\mathrm{Li}_{2} \mathrm{~B}_{4} \mathrm{O}_{7}\right)$ which explores metals in powder. The melted mixture was analyzed with the Fusion bead oxide method built in XRF software. Every sample was analyzed 3 times; these values were averaged.

\subsection{Methods}

\subsubsection{Laser particle size analyzer}

The particle size distribution (PSD) of the ground material was measured by a HORIBA LA-950V2 laser diffraction particle size analyzer in wet mode using distilled water as a dispersing media and sodium-pyrophosphate as a dispersing agent applying the Mie-theory as an evaluation method. Prior to the measurement, ultrasonic treatment was applied for $1 \mathrm{~min}$ in order to reach better dispersion of the suspension.

\subsubsection{Hardgrove Grindability Test}

The Hardgrove Grindability test procedure was carried out as follows: the feed mass was $50 \mathrm{~g}$ of $600 \ldots 1180$ $\mu \mathrm{m}$ size interval, the loading of the top grinding ring was $290 \mathrm{~N}$, the grinding time was $3 \mathrm{~min}$ (60 revolutions of the mill at a speed of $20 \mathrm{rev} / \mathrm{min}$ ). The test sieve was 75 $\mu \mathrm{m}$ and the Hardgrove Grindability Index (HGI) was determined using Equation 3:

$$
\mathrm{HGI}=13+6,93 \mathrm{~m}_{\mathrm{H}}
$$

Where:

HGI - Hardgrove Grindability Index (-),

$\mathrm{m}_{\mathrm{H}}$ - weight of the ground product passing $75 \mu \mathrm{m}(\mathrm{g})$.

According to the Csőke (Csőke et al., 2003 b) formula, the Bond work index can be calculated from the Hardgrove number as follows by using Equation 4:

$$
W_{B}^{H}=\frac{468}{H G I^{0,82}}
$$

Where:

$\mathrm{W}^{\mathrm{H}}{ }_{\mathrm{B}}$ - Bond work index calculated from $\mathrm{HGI}(\mathrm{kWh} / \mathrm{t})$,

HGI - Hardgrove Grindability Index (-),
This equation was validated for various minerals as well as for bauxite grinding in recent papers (Mucsi et al., 2011; Mucsi et al., 2016).

\subsubsection{Bond Grindability Test}

The Bond-method simulates closed-circuit grinding which is carried out in sections until the establishment of equilibrium. The Bond work index can be determined as follows using Equation 5:

$$
W_{i, B}=\frac{4,9}{x_{\max }^{0,23} G^{0,82}\left(\frac{1}{\sqrt{x_{80}}}-\frac{1}{\sqrt{X_{80}}}\right)}[\mathrm{kWh} / \mathrm{t}]
$$

Where:

$\mathrm{W}_{\mathrm{iB}}$ - Bond work index $(\mathrm{kWh} / \mathrm{t})$,

$\mathrm{x}_{\max }-$ max. particle size of product $(\mathrm{mm})$,

$\mathrm{G}$ - weight of sieve undersize per mill revolution in the Bond mill (g/revolution),

$\mathrm{X}_{80}-80 \%$ passing size of the product $(\mathrm{mm})$,

$\mathrm{X}_{80}-80 \%$ passing size of the feed $(\mathrm{mm})$.

\subsubsection{New grindability test and device}

The Hardgrove mill was equipped with a device suitable for the measurement of the grinding energy. Since the screw drive of this mill burdens a high energetic loss, the electric energy measurement method could not be applied reliably, therefore the determination of the grinding work was solved by a torque measuring device. This method, the so-called Universal Hardgrove mill test was reported recently in other papers (Mucsi, 2008, Mucsi and Csőke, 2010)

The mill was equipped with a simple torque-meter (load cell) which enabled direct measurement of the power delivered to the grinding chamber. (see Figure 1). For this reason, the whole grinding chamber (1) was mounted on an axial bearing (3), so it could rotate practically freely. This rotation was fixed by a force arm (5) connected into a force transducer (4). In this way, the torque necessary for the grinding could be measured.

The developed Universal Hardgrove mill consists of the following main parts:

1 - Grinding chamber,

2 - Control unit,

3 - Axial bearing,

4 - Torque-meter (load cell),

5 - Torque-meter arm,

6 - Starting unit.

Temperature can be set by a digital control unit (2) and the grinding energy (work) can be registered which is used for the calculation of specific grinding work. The grinding stress can be varied in a wide range up to $600 \mathrm{~N}$ compression force. Additionally, the temperature can be controlled in the range from 20 to $300^{\circ} \mathrm{C}$. 


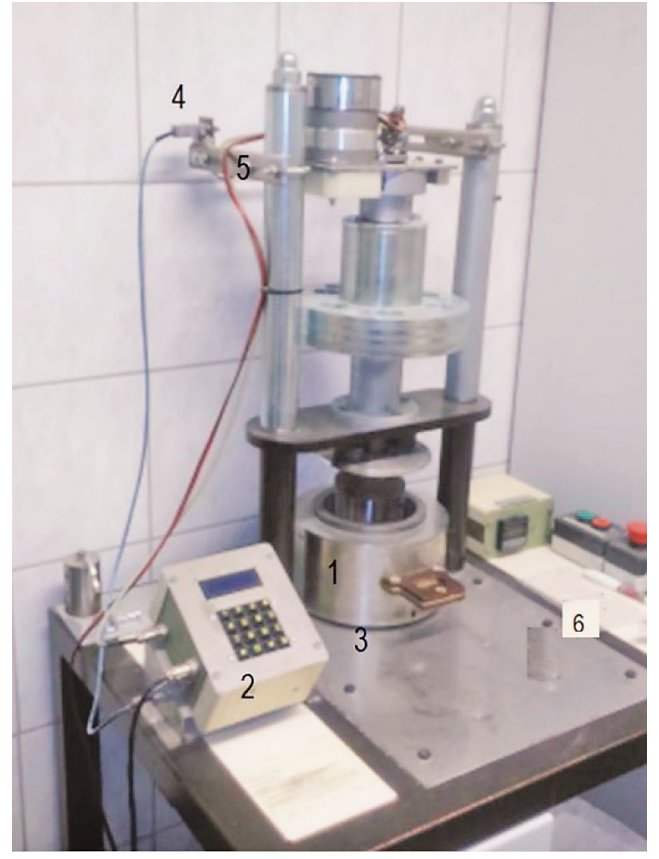

Figure 1. New Universal Hardgrove Mill

The rotation of the grinding chamber placed on the bearing was stopped by the torque meter arm. The torque (see Equation 6) is proportional to the measured force $\mathrm{F}(\mathrm{t})$ arisen on the arm $(\mathrm{k})$ :

$$
\mathrm{M}_{1}=\mathrm{kF}
$$

Where:

$$
\begin{aligned}
& \mathrm{M}_{1}-\text { grinding torque }(\mathrm{Nm}), \\
& \mathrm{k}-\text { torque } \operatorname{arm}(\mathrm{m}), \\
& \mathrm{F}-\text { force }(\mathrm{N}) .
\end{aligned}
$$

This torque relates to the turning moment of the driving axis: $\mathrm{M}_{1}=\mathrm{M}_{2}$. The angular velocity of this axis is $\omega$, hence performance $(\mathrm{P})$ can be calculated using Equation 7:

$$
\mathrm{P}=\mathrm{M}_{2} \omega .
$$

Where:

$$
\begin{aligned}
& \mathrm{P}-\text { performance }(\mathrm{W}), \\
& \mathrm{M}_{2}-\text { axis torque }(\mathrm{Nm}), \\
& \omega-\operatorname{angular} \text { velocity }(1 / \mathrm{s}) .
\end{aligned}
$$

Knowing the grinding torque $\mathrm{M}$ and the angular velocity $\left(\omega=2 \pi n ; n=20 \mathrm{~min}^{-1}\right)$, the instantaneous grinding power can be calculated. The control unit calculates the integral of the grinding power according to the time, i.e. the grinding work.

The specific grinding work (knowing no-load torque $\mathrm{M}_{0}$ ) can be calculated with Equation 8:

$$
W_{h}=\frac{\int_{0}^{\tau}\left\{2 \pi n\left[M(t)-M_{0}\right]\right\} d t}{m_{p}}
$$

Where:

$\mathrm{W}_{\mathrm{h}}$ - specific grinding work $(\mathrm{kWh} / \mathrm{t})$, $\mathrm{m}_{\mathrm{p}}$ - mass of the final product i.e. the mass of particles $<106 \mu \mathrm{m}$ in the mill product $(\mathrm{g})$,

$\mathrm{M}(\mathrm{t})$ - measured torque $(\mathrm{Nm})$,

$\mathrm{M}_{0}$ - no-load torque (Nm),

$\mathrm{n}-$ revolution number $(1 / \mathrm{s})$.

Therefore, the Bond-work index is calculated by Equation 9:

$$
W_{i B}=\frac{W_{h}}{\left(\frac{1}{\sqrt{x_{80}^{\prime}}}-\frac{1}{\sqrt{X_{80}^{\prime}}}\right)}
$$

Where:

$$
\begin{aligned}
& \mathrm{W}_{\mathrm{iB}}-\text { Bond work index }(\mathrm{kWh} / \mathrm{t}), \\
& \mathrm{W}_{\mathrm{h}}-\text { specific grinding work }(\mathrm{kWh} / \mathrm{t}), \\
& \mathrm{x}_{80}-80 \% \text { passing size of finished product }(<106 \mathrm{~mm}) \\
& \quad(\mu \mathrm{m}), \\
& \mathrm{X}_{80}-80 \% \text { passing size of the mill feed }(\mu \mathrm{m}) .
\end{aligned}
$$

As it is well known, it is reasonable to assume that various factors may affect the actual torque input to the grinding chamber, i.e. frictional, cohesive, adhesive and flow characteristics of the bulk material. These parameters are taken into account when specific grinding work is measured by torque measuring.

The method was carried out after the Bond test. The maximum particle size of the feed material was 3.15 $\mathrm{mm}$, and the volume was $58 \mathrm{~cm}^{3}$. The volume of the feed was determined using brown coal samples since originally the Hardgrove test was created to measure the grindability of coal. The bulk density of $50 \mathrm{~g}$ of three various brown coal samples was measured five times and it resulted in $58 \mathrm{~cm}^{3}$ as an average value, and originated from the average bulk density of $0.862 \mathrm{~g} / \mathrm{cm}^{3}$. The closed cycle grinding was performed until the grindability coefficient $G(G=$ weight of sieve undersize per mill revolution in the Hardgrove mill) reached the steady state conditions in the three last cycles, constant $\mathrm{G}$ value. The compression force on the material being ground was constant at $290 \mathrm{~N}$ during the measurement as suggested in the Hardgrove procedure. The mill revolution in the first cycle was 100 as in the Bond test. Calculation of the mill revolution of the next grinding cycle similarly to Bond method is as follows (see Equation 10):

$$
N_{i+1}=\frac{0,286 m_{t}-m_{M i} \Delta m(x<106 \mu m)}{G_{i}}
$$

Where:

$\mathrm{N}_{\mathrm{i}+1}$ - revolution of the next grinding cycle ( $\left.1 / \mathrm{min}\right)$,

$\mathrm{m}_{\mathrm{t}}$ - mass of the total feed $(\mathrm{g})$,

$\mathrm{m}_{\mathrm{Mi}}-$ mass of mill product finer than $106 \mu \mathrm{m}(\mathrm{g})$,

$\Delta \mathrm{m}(\mathrm{x}<106 \mu \mathrm{m})$ - mass of material finer than $106 \mu \mathrm{m}$ being present in the original feed $(\mathrm{g})$,

$\mathrm{G}_{\mathrm{i}}$ - weight of sieve undersize per mill revolution of the cycle ,i“ (g/revolution).

The $80 \%$ passing size of the feed and the product can be determined from the particle size data. However, it 
must be highlighted that the above Equation 10 is based on a $250 \%$ circulating load as it is in the Bond test, but that of the ring mill can be varied from 1 up to 10 in industrial practice (Boehm et al, 2015). Therefore, the effect of this parameter will be investigated in detail in the future.

\section{Results and discussion}

\subsection{Conventional Hardgrove grindability test}

As a first step of the research, a conventional Hardgrove test (according to ASTM D409-71) was carried out for each sample. The measurements were performed in triplicate and the HGI average calculated with Equation 3 is shown in Table 2. The difference in the results for the same material does not exceed the 3\% limit value. Moreover, the Bond work index was calculated using Equation 4.

It can be seen from the results that the limestone sample has the lowest grinding resistance $\left(\mathrm{W}_{\mathrm{iB}}=12.01\right.$ $\mathrm{kWh} / \mathrm{t})$. On the other hand, the andesite, basalt and sand samples are characterized as hardly-to-ground materials with Bond work indices of $21.52 \mathrm{kWh} / \mathrm{t}, 19.07 \mathrm{kWh} / \mathrm{t}$ and $19.92 \mathrm{kWh} / \mathrm{t}$ respectively. Finally, the clinker was found to be a medium grindability material with a Bond work index of $16.37 \mathrm{kWh} / \mathrm{t}$.

Table 2. Hargdrove Grindability Index (HGI) and calculated Bond work index $\left(\mathrm{W}_{\mathrm{iB}}\right)$ of the samples

\begin{tabular}{|l|c|c|}
\hline Sample & HGI, - & $\begin{array}{c}\mathbf{W}_{\text {iB }} \text { (calculated from } \\
\text { HGI), } \boldsymbol{k} \boldsymbol{W h} / \boldsymbol{t}\end{array}$ \\
\hline Sand & 46.99 & 19.92 \\
\hline Limestone & 87.06 & 12.01 \\
\hline Andesite & 42.77 & 21.52 \\
\hline Basalt & 49.56 & 19.07 \\
\hline Clinker & 59.58 & 16.37 \\
\hline
\end{tabular}

\subsection{Bond grindability test}

After carrying out the conventional Hardgrove test, the well-known Bond grindability test was performed for each material. The Bond work index was determined using Equation 5 after measuring the grindability coefficient $(\mathrm{G})$, and the $80 \%$ passing size of the feed $\left(\mathrm{X}_{80}\right)$ and the product $\left(\mathrm{x}_{80}\right)$.

In order to compare the fineness of the feed samples, the cumulative particle size distribution curves are shown in Figure 2. It can be established that the finest particle size distribution belongs to the sand and andesite sample, while the coarsest one was the basalt. Limestone and clinker were characterized as similarly fine materials. However, if the size fraction of $<106 \mu \mathrm{m}$ is taken into consideration for comparison, the fineness is in the order: andesite $>$ limestone $>$ clinker $>$ sand $>$ basalt. These

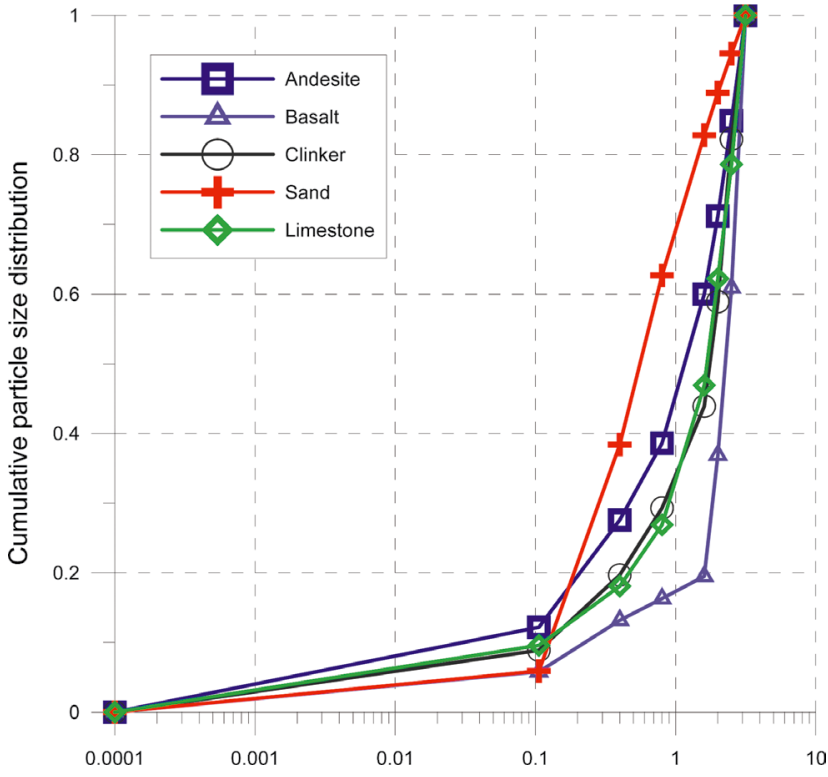

Figure 2. Particle size distribution of the feed

feed materials were used as feed for the Bond as well as for the volume based closed-cycle Hardgrove tests.

In order to investigate the grinding behaviour of the various materials, after each grinding cycle the grindability coefficient $(\mathrm{G})$ is demonstrated as a function of the grinding steps in Figure 3. As a general phenomenon, it was observed that the $\mathrm{G}$ value became constant in the last three cycles in all the cases as it is required according to Bond test procedure description. However, the tendency was very different depending on the material used.

The sedimentary rocks (limestone and sand) behave similarly from this point of view. The initial slight de-

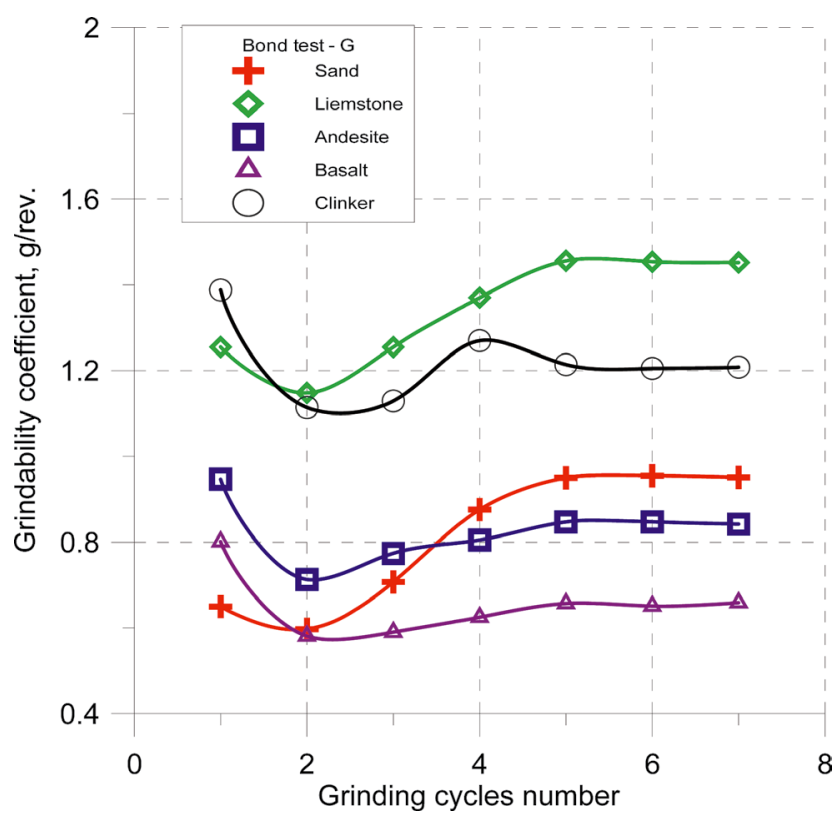

Figure 3. Variation of the grindability coefficient of the Bond test as a function of grinding cycles 
Table 3. Results of the Bond grindability test

\begin{tabular}{|l|c|c|c|c|}
\hline Sample & Feed $\mathbf{X}_{\mathbf{8 0}}, \boldsymbol{\mu m}$ & ${\text { Product } \mathbf{x}_{\mathbf{8 0}}, \boldsymbol{\mu m}}$ & Grindability coeff. G, g/rev. & Bond work index, $\mathbf{W}_{\mathbf{i B}}, \mathbf{k W h} / \mathbf{t}$ \\
\hline Sand & 1790 & 85 & 0.95 & 20.59 \\
\hline Limestone & 2440 & 69 & 1.45 & 12.39 \\
\hline Andesite & 2165 & 70 & 0.84 & 19.73 \\
\hline Basalt & 2530 & 57 & 0.65 & 21.08 \\
\hline Clinker & 2453 & 89 & 1.21 & 17.05 \\
\hline
\end{tabular}

crease of the $G$ value was followed by a section of linear increase, and finally it became constant in the last three cycles.

Contrary to the previously presented sedimentary rocks, volcanic rocks behave differently concerning the $\mathrm{G}$ values. The shape of the andesite and basalt curves were similar to each other. Namely, they started with relatively high values followed by a sudden decrease in the second cycle. From the third step, the mass of $<106$ micron material started to grow gradually before the constant section.

Regarding the clinker sample as a product of the calcination of minerals (mainly limestone and clay) behave similarly to the volcanic rocks, e. g. started from a high-

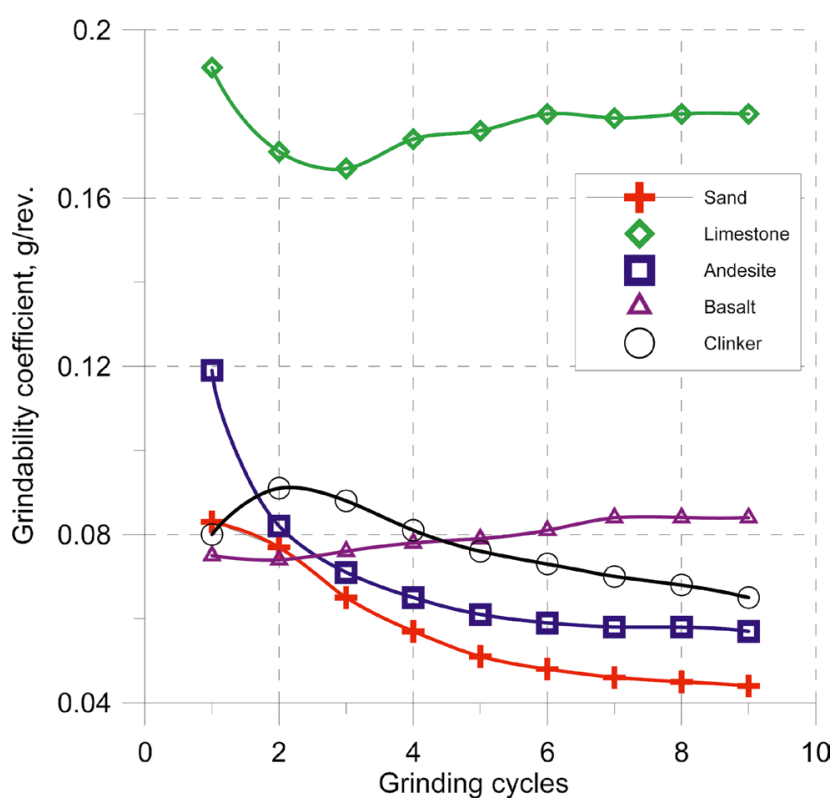

Figure 4. Grindability coefficient of the closed cycle Hardgrove test er value then decreased followed by a slight fluctuation section before the constant stage.

The results of the Bond grindability measurements, i.e. grindability coefficient, $80 \%$ passing size of the feed and the product are summarized in Table 3. A constant grindability coefficient was reached after at least 7 cycles in all cases.

The product fineness $\left(\mathrm{x}_{80}\right)$ and grindability coefficient (G) of the Bond test are of the most significant effect on the value of the Bond work index. The coarsest product was achieved in the case of clinker and sand with $89 \mu \mathrm{m}$ and $85 \mu \mathrm{m} \mathrm{x}_{80}$ respectively, on the other hand, basalt resulted in the finest product characterized with $57 \mu \mathrm{m}$ $80 \%$ passing particle size. Andesite and limestone fineness were between them, $70 \mu \mathrm{m}$ and $69 \mu \mathrm{m}$. Regarding the grindability coefficient, the finest basalt resulted in the lowest and limestone had the highest $G$ value. In terms of the Bond work index, limestone behaved as the easiest-to-grind and sand and basalt as the hardest-togrind materials. These results are correlated well with the Hardgrove based Bond work index (see Table 2).

\subsection{Volume based closed-cycle Hardgrove test}

The results of the new suggested method are presented and discussed based on the grindability coefficient, $80 \%$ passing size of the product and the grindability indices.

\subsubsection{Grindability coefficient}

Figure 4 shows the variation of the grindability coefficient $(G)$ of the samples related to the volume based closed-cycle Hardgrove test as function of the grinding cycle number. It can be clearly seen that the limestone sample has a significantly higher G value $(0.181 \mathrm{~g} / \mathrm{revo-}$ lution). On the other hand, the sand sample resulted in the lowest coefficient, namely $0.046 \mathrm{~g} /$ revolution. Fur-

Table 4. Grindability coefficient of the closed circuit Hardgrove test

\begin{tabular}{|l|c|c|c|c|c|c|}
\hline Sample & $\mathbf{G}_{\mathbf{I}}$ & $\mathbf{G}_{\text {II }}$ & $\mathbf{G}_{\text {III }}$ & $\mathbf{G}_{\text {average }}$ & Deviation & Relative deviation [\%] \\
\hline Sand & 0.048 & 0.045 & 0.044 & 0.046 & 0.00183 & 3.99 \\
\hline Limestone & 0.183 & 0.180 & 0.180 & 0.181 & 0.00192 & 1.06 \\
\hline Andesite & 0.057 & 0.058 & 0.057 & 0.058 & 0.00034 & 0.58 \\
\hline Basalt & 0.080 & 0.083 & 0.084 & 0.082 & 0.00236 & 2.86 \\
\hline Clinker & 0.064 & 0.066 & 0.064 & 0.065 & 0.00110 & 1.70 \\
\hline
\end{tabular}


Table 5. Product fineness $\left(\mathrm{x}_{80}\right)$ of closed circuit Hardgrove test

\begin{tabular}{|c|c|c|c|c|c|c|}
\hline Sample & $x_{80, I}, \mu m$ & $x_{80, I I}, \mu \mathrm{m}$ & $x_{80, I I I}, \mu \mathrm{m}$ & $x_{80, \text { aver }}, \mu \mathrm{m}$ & Deviation & Relative deviation, \% \\
\hline Sand & 71.33 & 74.97 & 72.37 & 72.89 & 1.87 & 2.57 \\
\hline Limestone & 46.00 & 45.33 & 40.80 & 44.04 & 2.83 & 6.42 \\
\hline Andesite & 77.07 & 77.67 & 76.07 & 76.94 & 0.81 & 1.05 \\
\hline Basalt & 68.77 & 71.23 & 68.23 & 69.41 & 1.60 & 2.30 \\
\hline Clinker & 79.90 & 81.63 & 81.33 & 80.95 & 0.92 & 1.14 \\
\hline
\end{tabular}

thermore, it is established that in this case, there was no similar trend in sedimentary nor in volcanic raw materials. A constant grindability coefficient was achieved after a maximum of 9 cycles.

Table 4 shows the grindability coefficient of the closed circuit Hardgrove test obtained in the three experimental series (I., II. and III.). Namely, the triplicate results of the last 3 cycles $\left(\mathrm{G}_{\mathrm{I}}, \mathrm{G}_{\mathrm{II}}, \mathrm{G}_{\mathrm{III}}\right)$ and the average $\left(\mathrm{G}_{\text {average }}\right)$ is presented. It can be stated that deviation of the results is relatively low, from 0.00034 to 0.00236 , additionally the relative deviation was found to be from 0.58 to $3.99 \%$.

\subsubsection{Product fineness}

The finest product was achieved (see Table 5) in the case of the limestone sample $\left(\mathrm{x}_{80}=44.04 \mu \mathrm{m}\right)$ and the coarsest one was found in the clinker sample $\left(\mathrm{x}_{80}=80.95\right.$ $\mu \mathrm{m})$. Basalt $\left(\mathrm{x}_{80}=69.41 \mu \mathrm{m}\right)$, andesite $\left(\mathrm{x}_{80}=76.94 \mu \mathrm{m}\right)$ and sand $\left(\mathrm{x}_{80}=72.89 \mu \mathrm{m}\right)$ were between these values.

Reproducibility of the $80 \%$ passing particle size results was very high. The relative deviation for andesite and clinker was approximately $1 \%$, while for basalt and sand, it was about $2.5 \%$. However, limestone resulted in the highest relative deviation with $6.42 \%$. This can be explained by the relatively soft nature of limestone which resulted in the aggregation of the fine particles especially in the size range below $50 \mu \mathrm{m}$.

Table 6 shows the specific grinding work results of the proposed test. Compared with the previously presented results, it can be stated that the new test resulted in higher values in most cases except for limestone and basalt.

In the case of the sand sample, the closed-cycle HGI test resulted in more than a 1.5 time higher Bond work index value than that of the conventional methods. On the other hand, limestone resulted in a $36 \%$ lower Bond work index using the new method compared with the traditional numbers. In this latter case, a similar difference $(\sim 35 \%)$ was found between the industrial Bond work index of an industrial ring mill $(50 \mathrm{t} / \mathrm{h})$ and the laboratory Bond work index was calculated from HGI (Árvai, 2008) which is in correspondence with the better energy efficiency of a bowl mill.

There might be several reasons for the above discrepancies. A possible reason for the bad correlation might be that the ratio of the grinding ball (compression force)
Table 6. Closed cycle volume based on the Hardgrove grindability test results

\begin{tabular}{|l|c|}
\hline Sample & Closed cycle Hardgrove $\mathbf{W}_{\mathbf{i B}},[\mathbf{k W h} / \mathbf{t}]$ \\
\hline Sand & 33.74 \\
\hline Limestone & 7.67 \\
\hline Andesite & 26.10 \\
\hline Basalt & 19.03 \\
\hline Clinker & 23.55 \\
\hline
\end{tabular}

and maximum particle size of the material being ground is not high enough, and in this way, there is not enough stress on the particles for particle size reduction (in the case of Bond ball mill test max. media size is $40 \mathrm{~mm}$ !). This is supported by the result that the softest material (limestone) behaves as expected, and resulted in a lower specific grinding energy in ring mill than in the ball mill. On the other hand, the hardest materials (with strong intermolecular cohesion forces) cannot be comminuted easily by the compression which occurs in the Hardgrove mill. To overcome this problem, two possible experimental conditions can be modified: 1) increase the compressing stress or 2) decrease the feed particle size.

Additionally, it is important to note that these materials have various friction coefficients, hence the condition of nip is not satisfied in the case of low coefficient materials, like sand might result in high specific grinding work. Based on literature, the lowest friction coefficient (Cobb, 2008) was found to be in the case of quartz (0.4$0.5)$, however the limestone resulted in the highest number $(\mu=0.75)$. Consequently, if the particle shape is more or less identical, the limestone has better conditions to be ground which will decrease the grinding work.

\section{Acknowledgment}

The described work was carried out in the framework of the Centre of Excellence in Sustainable Natural Resources Management at the Faculty of Earth Science and Engineering, University of Miskolc. The authors appreciate the X-ray Fluorescence measurements for Mr. Ferenc Móricz in order to determine the chemical composition of the raw materials.

The described article was carried out as part of the "Sustainable Raw Material Management Thematic Network - RING 2017', EFOP-3.6.2-16-2017-00010 pro- 
ject in the framework of the Széchenyi2020 Program. The realization of this project is supported by the European Union, co-financed by the European Social Fund.

\section{Conclusions}

Based on the experimental results the following conclusions were drawn:

- The reproducibility of the proposed grindability test was very good since the relative deviation of the examined parameters were low.

- The above presented method can be used both for systematic laboratory experiments as well as for optimization of the operating conditions of industrial ring mills.

- Through comparison of the new test results with those of the well-known procedures, it can be seen that the value of the specific grinding work strongly depends on the used grinding stress since there are different grinding phenomenon in ball and ring mills.

- The main benefit of this method compared to traditional standardized methods lies in its fast determination possibility, which can be used for industrial daily control measurement of the grinding circle as well. Additionally, the direct measurement of grinding energy can be managed by using the developed Volume based closed-cycle Hardgrove grindability method in order to receive very punctual data.

- Of course, there are many questions which have to be investigated in future studies, such as the effect of the circulating load, the feed particle size and the compressing force. Therefore, it is planned to continue our research in this direction.

\section{References}

Agus, F., Waters P. (1971): Determination of the grindability of coal, shale and other minerals by a modified Hardgrove machine method. Fuel, 50, 405-431.

Árvai, G. (2008): Grindability investigation of limestone from OMYA plant in Felnémet. Diploma thesis, Miskolc (In Hungarian) $62 \mathrm{p}$.

Beke, B. (1974): Anyagok őrölhetősége és az őrölhetőség méröszáma. Journal of Silicate Based and Composite Materials, 26, 12, 449-455.

Boehm, A., Meissner, P., Plochberger, T. (2015): An energy based comparison of vertical roller mills and tumbling mills. International Journal of Mineral Processing, 136, 37-41.

Bond, F.C., Maxson W.L. (1943): Standard grindability tests and calculations. Trans. Soc. Min. Eng. AIME, 153, 362-372.

Bond, F. C. (1954): Crushing and grinding calculations. CÍM Bulletin, 47, 507, 466-472.

Bond, F.C. (1961): Crushing and grinding calculations I-II. British Chemical Engineering, 1-14.
Bond, F.C. (1964): Berechnungsmethode zur Feinzerkleinerung (Evaluation of fine particle grinding) Aufbereitungstechnik, 5, 211-218.

Cobb, F. (2008): Structural Engineer's Pocket Book. 2nd Edition: British Standards Edition, 395 p.

Csőke, B., Bokányi, L., Bőhm, J., Pethő, Sz. (2003 a): Selective grindability of lignites and their application for producing an advanced fuel. Applied Energy, 74, 359-368.

Csőke, B., Hatvani, Z., Faitli, J., Solymár, K, Papanastassiou, D. (2003 b): New test method for investigation of grindability in alkaline media at high temperature. In: Lorenzen, L. (ed.) XXIII International Mineral Processing Congress, Cape Town - South African Institute of Mining and Metallurgy, 434-441.

Deister, R.J. (1987): How to determine the Bond work index using lab ball mill grindabilitytests. E\&MJ, 42-45.

Deniz, V., Sütcü, N., Umucu, Y. (2003): The effect of Circulating Load and Test Sieve Size on The Bond Work Index Based on Natural Amorphous Silica, 18th International Mining Congress and Exhibition of Turkey-IMCET, 517-522.

Dvorák, K., Dolák, D., Vsianský, D., Dobrovolný P. (2016): Evaluation of The Grindability of Recycled Glass in the Production Of Blended Cements. Materiali in tehnologije / Materials and technology, 50, 729-734.

Gável, V., Opoczky, L., Sas, L. (2000): A technológiai paraméterek és a klinker szövetszerkezete, valamint örölhetősége közötti összefüggések. Journal of Silicate Based and Composite Materials, 52, 34-38. (In Hungarian)

Haese, U., Scheffler, P., Fasbender H. (1975): Mahlbarkeitsprüfung und Rohrmühlenauslegung bei Zementrohstoffen (Grindability testing and tube mill design for cement raw materials). Cement-Kalk-Gips, 8, 316-324.

Juhász, A.Z., Opoczky, L. (1990): Mechanical activation of minerals by grinding: pulverizing and morphology of particles. Akadémiai Kiadó, Budapest, 234 p.

Levin, J. (1989): Observation on the Bond standard grindability test and a proposal for a standard grindability test for fine materials. SAIMM, 89, 1, 13-21.

Magdalinovic, N. (1989): Calculation of Energy Required for Grinding in a Ball Mill. International Journal of Mineral Processing, 25, 41-46.

McIntyre, A., Plitt, L. (1980): The interrelation between Bond and Hardgrove Grindabilities. CIM Bulletin, 73, 818, 149-154.

Morrell, S. (2004): An alternative energy-size relationship to that proposed by Bond for the design and optimisation of grinding circuits. Int. J. Miner. Process., 74, 133- 141.

Mucsi, G. (2008): Fast test method for the determination of the grindability of fine materials. ELSEVIER, Chemical Engineering Research and Design, 86, 4, 395-400.

Mucsi, G., Csőke, B. (2010): Development of Grindability Tests Based on Direct Measurement of Energy. XXV International Mineral Processing Congress, Brisbane, Australia The Australasian Institute of Mining and Metallurgy Publication Series, 7, 1047-1055.

Mucsi, G., Molnár, Z., Géber, R., Ferenczi, T., McGuiness, L., Csőke, B. (2016) Bauxite grindability at elevated tempera- 
ture in various mills. International Journal of Mineral Processing, 153, 8-16.

Mucsi, G., Csőke, B., Solymár, K. (2011): Grindability characteristics of lateritic and karst bauxites. International Journal of Mineral Processing, 100, 3-4, 96-103.

Mucsi, G., Rácz, Á., (2017): Grinding kinetics of red grape seed residue in stirred media mill. Advanced Powder Technology, 28, 10, 2564-2571.

Mucsi, G., Szabó, R., Rácz, Á., Kristály, F., Kumar, S. (2019): Combined utilization of red mud and mechanically activated fly ash in geopolymers. The Mining-Geology-Petroleum Engineering Bulletin (Rudarsko-geološko-naftni zbornik), 44, 27-36.

Nagy, L. (2010): Energy optimization of the grinding process in operating condition (Az őrlési folyamat energia-optimalizálása az Omya Hungária Kft.-nél). Journal of Silicate Based and Composite Materials, 62, 3, 79-82. (In Hungarian)

Senetakis, K., Coop, M.R., Todisco, M.C. (2013): The interparticle coefficient of friction at the contacts of Leighton Buzzard sand quartz minerals, Soils and Foundations, 53, $5,746-755$.
Shi, F., Zuo, W. (2014): Coal breakage characterisation - Part 1: Breakage testing with the JKFBC. Fuel, 117, Part B, 1148-1155.

Shi, F. (2014 a) Coal breakage characterisation - Part 2: Multi-component breakage modelling. Fuel, 117, Part B, 1156-1162.

Shi, F. (2014 b) Coal breakage characterisation - Part 3: Applications of the multi-component model for HGI prediction and breakage simulations. Fuel, 117, Part B, 1163-1169.

Smith, R. W., Lee, K. H. (1968): A comparison of Data from Bond Type Simulated Closed-Circuit and Batch Type Grindability Tests. Trans. SME-AIME, 241, 99-101.

Standard Test Method for Grindability of Coal by HardgroveMachine Method. 1931. ASTM D409-71

Todorovic, D., Trumic, M., Andric, L., Milosevic, V., Trumic, M. (2017): A Quick Method For Bond Work Index Approximate Value Determination. Physicochem. Probl. Miner. Process., 53, 1, 321-332.

Zeisel, H. G. (1953): Schriftenreihe der Zementindustrie. 14, Verein Deutcher Zementwerke, Düsseldorf, 51 p.

\section{SAŽETAK}

\section{Volumna metoda zatvorenoga ciklusa određivanja Hardgroveova indeksa meljivosti}

Prikazan je razvoj volumne metode zatvorenoga ciklusa meljivosti temeljen na nedavno uvedenome univerzalnom Hardgroveovu mlinu i postupku. Odabrano je pet materijala različita podrijetla i svojstava (čvrstoća, meljivost, heterogenost), poimence vapnenac, kvarc, andezit, bazalt i tvrdo pečena cigla. Meljivost je usporedno određena na četiri načina: (1) standardnim Hardgroveovim testom meljivosti (engl. skr. HGI), (2) indeksom vezivanja određenim iz HGI-ja, (3) konvencionalnim testom vezivanja, (4) volumenom zatvorenoga ciklusa temeljenom na meljivosti u univerzalnome mlinu. Određeni su koeficijenti meljivosti (engl. skr. G) te kumulativna raspodjela veličine čestica na 80 \% promjera (x 8o). Relativna odstupanja tih parametara bila su vrlo dobra, tj. uglavnom manja od $3 \%$, što je novu metodu istaknulo kao robustan postupak za određivanje specifične energije meljivosti u zatvorenome sustavu mlina. Stoga je takav test pogodan za određivanje meljivosti i njezinu optimizaciju na brz i pouzdan način.

\section{Ključne riječi:}

univerzalni Hardgroveov mlin, ideks vezivanja, meljivost, specifično mljevenje, zatvoreni ciklus

\section{Authors contribution}

Gábor Mucsi (PhD, Associate Professor) provided the evaluation of the overall experimental results, interpretations and presentation of the results. Ádám Rácz (PhD, Assistant Professor) provided the evaluation of the Bond tests. Gergely Mag (MSc Student, researcher) provided the raw material preparation and Hardgrove tests. Gábor Antal (Senior researcher) performed the mechanical engineering development of the machine. Barnabás Csőke (CSc, Professor Emeritus) performed interpretation of the test results. 